\title{
Quality Testing of Solid Soap with Mango Leaf Extract (Mangifera indica L.) Produced by Hot and Cold Processes
}

\author{
Zulfa Nurul Karimah*, Riska Kristiana \\ Chemistry Education Program, Faculty of Science \& Technology, UIN Sunan Kalijaga, \\ Jl. Marsda Adisucipto No.1 Yogyakarta 55281, Indonesia. \\ Email*: zulfanurulkarimah123@gmail.com
}

\begin{abstract}
Mango leaves (Mangifera indica L.) contain alkaloids, flavonoids, stereoid compounds, polyphenols, tannins and saponins. The saponin content in mango leaves is able to act as a natural foaming agent. Mango leaf extract can be added in the manufacture of solid soap to produce natural soap. Making solid soap can be done through heating (heat process) and without heating (cold process). This study aims to determine the process of making solid soap in a hot and cold process, comparing the best quality soap analysis based on quality including organoleptic testing and $\mathrm{pH}$ balance. The results showed the average quality of the best soap through the heat process with the results of organoleptic tested.
\end{abstract}

Keywords: Cold process, heat process, mango leaf extract, solid soap

\section{INTRODUCTION}

Mango plants are fruit plants that have the potential to be developed because they have a high level of genetic diversity. Mango leaves vary in terms of shape, size and color of the leaves, which shows considerable genetic diversity. The difference in leaf features of each type of plant makes leaves as one of the references for classifying each type of plant (Fu and Chi, 2006). One of them is potential as a medicinal plant. Mango plants (Mangifera indica L.) are plants that have the potential as herbal medicines because they contain secondary metabolite compounds (Ningsih et al., 2017). The part of the mango plant that is rarely used is the leaves. Mango plant leaves can be one of the additional ingredients in making soap, especially bathing soap. Besides mango plants are also very easily found in various regions so that it is easy to find. Bathing soap is one thing that is needed in society. Because soap is a means to cleanse itself from dirt, namely bacteria and germs. In addition to cleaning themselves, soap that is much in demand in the community that is soap that has benefits for the skin and also gives fragrance. The process of soap formation is known as saponification, which is the reaction between fat/triglyceride and alkali. Alkaline commonly used are $\mathrm{NaOH}$ and $\mathrm{KOH}$. Soap molecules consist of long hydrocarbon-like chains. The hydrocarbons consist of carbon atoms with very polar or ionic groups at one end. Carbon chains are lipophilic (dissolved in fats and oils) and hydrophilic polar ends (dissolved in water) (Gusviputri et al., 2013).

Mango leaf extract (Mangifera indica L.) has been studied containing tannins, flavonoids, terpenoids, and alkaloids and has anthelmintic activity in Phertima posthma (Indian earthworm) (Patil et al., 2014). Researches that have been carried out on mango plants are mango leaves as antioxidants, antimicrobials, and antitumor. Mango plant flavonoids also contain saponins, error tannins, katekat tannins, quinones and steroids or tripenoids (Widijanti and Bernard, 2007). Mango leaves are extracted masemari using methanol as a solvent. This study aims to compare the two methods of the soap making process, namely the cold and hot process and compare the quality of soap based on qualitative testing.

\section{MATERIALS AND METHODS}

\section{Raw materials}

Freshly harvested, old mango leaf were obtained from garden in campus UIN Sunan Kalijaga Yogyakarta. The variety of the mango leaf was golek mango. Only mango leaf wich had not spot were selected. Mango leaves are dried in the sun for two weeks to remove the water content.

The solvents used for the extraction of the mango leaf are methanol $75 \%$. The chemical used to making soap is Natrium hidroksida, palm oil, ethanol $96 \%$, stearic acid, glycerin, sodium chloride and sugar.

\section{Extraction of mango leaf}

Mango leaves that have dried and then pollinated and sifted. Mango leaf extracted by maceration method. A total of 50 grams of simplicia was immersed in $500 \mathrm{~mL}$ of $75 \%$ methanol $(1: 10)$ for 12 hours. The filtrate was 
evaporated at $50{ }^{\circ} \mathrm{C}$ for 3 hours until a thick extract was obtained.

\section{Hot processes \\ Making soap with hot processes. As much as $60 \mathrm{~g}$ of palm oil is heated until the material temperature reaches $70^{\circ} \mathrm{C}, 30 \mathrm{~g}$ stearic acid is mixed into the beaker glass while stirring until thoroughly mixed at $70^{\circ} \mathrm{C}-80^{\circ} \mathrm{C}$, $73 \% \mathrm{NaOH} 30 \% \mathrm{NaOH}$ is added to the palm oil mixture and stearic acid, then stir until homogeneous, 96\% ethanol added as much as $45 \mathrm{~g}$. Glycerin $39 \mathrm{~g}, \mathrm{NaCl}$ (Sodium Chloride) $1.5 \mathrm{~g}$, granulated sugar 22, g, and distilled water $19.5 \mathrm{~g}$ added respectively, stirring with constant speed at a material temperature of $70^{\circ} \mathrm{C}-80^{\circ} \mathrm{C}$ until the ingredients are thoroughly mixed and the mixture looks transparent. Soap mixture is added by $1 \%$ mango leaf extract and then poured in a mold.}

\section{Cold processes}

Making soap with cold process. As much as 60 grams of palm oil are mixed with $30 \% \mathrm{NaOH}$ as much as 31.5 grams then stir until homogeneous. Soap mixture is added by $1 \%$ mango leaf extract and stirred until homogeneous. The mixture is poured into a mold.

\section{Soap quality testing}

Testing the quality of soap through qualitative analysis includes organoleptic testing and $\mathrm{pH}$ testing. The Organoleptic tests include: color, aroma, transparency of soap, hardness and lots of foam produced using the senses of sight, taste, and touch.

\section{RESULTS AND DISCUSSION}

The difference in the process of making solid soap from mango leaf extract is distinguished through two processes namely cold and hot process. Both of these processes are based on the addition of heat during the soap making process. Sometimes, some soap making processes will be better if not added hot. The study was conducted to find out the suitable method for the process of making soap by adding mango leaf extract.

\section{The process of making soap with a hot process and a cold process}

The addition of mango leaf extract is done in the same amount of composition. This addition is done when the soap mixture has been mixed. Mango leaf extract is rather difficult to dissolve in the soap mixture so that the stirring factor becomes the most important thing in the homogeneity of the soap. The process of adding mango leaf extract to the heat process is done when the dough temperature is not too high so that the components in the extract are not damaged. The process of adding extracts must be carried out at temperatures around $56-65^{\circ} \mathrm{C}$, this is due to the temperature below that the soap mixture is already in a thick state so that it causes air bubbles in the soap when stirring The process of printing soap is done as fast as possible before the soap can harden. The process of adding mango leaf extract to the cold process is done after mixing palm oil with $\mathrm{NaOH}$. Mango leaf extract functions as a soap-filled additive. Cold process is carried out without the addition of heat. The main factor for the success of this process depends on the stirring process. Mixing that is too low causes the resulting soap to be inhomogeneous or causes two phases. The texture of the soap mixture in the cold process is thicker than in the process hot but has a lower level of violence.

\section{Organoleptic test}

Table 1. The Results of organoleptic test.

\begin{tabular}{|l|l|l|l|l|l|}
\hline \multirow{2}{*}{ Process } & \multicolumn{5}{|c|}{ Hasil Pengujian } \\
\cline { 2 - 6 } & Colour & aromatic & Transparant & Solidty & Foam \\
\hline Hot & $\begin{array}{l}\text { Fresh } \\
\text { Yellowish } \\
\text { green }\end{array}$ & Typical & Transparant & solid & foamy \\
\hline Cold & $\begin{array}{l}\text { Pale } \\
\text { Yellowish } \\
\text { green }\end{array}$ & Typical & Opaque & solid & foamy \\
& & & & \\
\hline
\end{tabular}

Organoleptic test results include color, aroma, transparency, hardness, and foam in cold and hot processes. The results of color testing on hot processes soap has a fresher color appearance compared to cold processes. Cold process soap tends to be pale. Results fragrance testing on typical scented soap mango leaf extract. Both of these manufacturing processes, the addition of fragrance is not done so that the resulting aroma only comes from the fragrance of mango leaf extract. However, the resulting aroma is not liked so for the next process must be added fragrance. Transparency testing results, the soap produced from the hot process has a high level of transparency while the soap from the cold process has a low level of transparency (opaque). The results of testing the level of hardness of the soap from the hot process are harder and rougher than the soap from the cold process. Soap from the cold process is textured harder but softer. The foam test results show that soap from the hot process has a lower amount of foam but is more durable, whereas soap from the cold process has a higher amount of foam but does not last long. The results of $\mathrm{pH}$ testing, soap has a basic $\mathrm{pH}$ and both methods show the same results.

\section{CONCLUSIONS}

The process of making solid soap is done through two different methods. The method of making soap with a hot process is carried out at high temperatures with thick 
consistency. The temperature factor is the main factor in this process. The method of making soap with a cold process is carried out at low temperatures with a liquid consistency. The organoleptic test results of the soap from the heat process are higher so that the process of making soap with mango leaf extract is more suitable to use the heat process.

\section{REFERENCES}

Fu H, Chi Z. 2006. Combined Thresholding and Neural Network Approach for Vein Pattern Extraction from Leaf Images. Image Signal Process IEEE 153(6).
Gusviputri A, Meliana N, et al. 2013. Pembuatan Sabun dengan Lidah Buaya (Aloe Vera) Sebagai Antiseptik Alami.

Ningsih DR, Zusfahair, Mantari D. 2017. Ekstrak Daun Mangga (Mangifera Indica L.) Sebagai Antijamur Terhadap Jamur Candida Albicans dan Identifikasi Golongan.

Patil D, Halle P, Bade A. 2014. Invitro Anthelmintic Activity of Methanolic Extract of Mangifera indica Leaves. World J Pharm Sci 3(12): 771-776.

Widijanti A, Bernard TR. 2007. Pemeriksaan Laboratorium Penderita Diabetes Melitus. 
THIS PAGE INTENTIONALLY LEFT BLANK 